\title{
Conservation of breeding colonies of the bank myna, Acridotheres ginginianus (Latham 1790), in Chapai Nawabganj, Bangladesh
}

\author{
M Farid Ahsan and M Tarik Kabir \\ Department of Zoology, University of Chittagong, Chittagong, Bangladesh
}

\begin{abstract}
Abstact: A study on the conservation on breeding colonies of bank myna, Acridotheres ginginianus (Latham 1790), was conducted in Chapai Nawabganj district of Bangladesh during a period from June 2007 to October 2009. The total population in the breeding colonies was estimated as 4,452 . The preferable breeding habitats of bird are bank of the river, soil heap/ditches of brickfield and holes of culvert. Environmental calamities such as bank erosion and flooding, drought and rain affect the breeding colonies. Human settlement near breeding habitats, hunting, collecting eggs and nestlings by children, and use of nets to prevent nesting at bank of the river are the main human impacts on the breeding colonies. Major threats are flood, children-fun, predators and human for its meat. Conservation awareness for this species have depicted in this paper.
\end{abstract}

Key words: Conservation, breeding colonies, bank myna, Acridotheres ginginianus, Chapai Nawabganj, Bangladesh.

\section{Introduction}

Conservation biology is the new multidisciplinary science that has developed to deal with disaster of biological diversity (Primack, 2006). To investigate human impact on biological diversity and develop practical approaches to prevent the extinction of species are the main goal of conservation biology (Soule, 1985; Wilson, 1992). It also creates link between conservation priorities and human needs.

Acridotheres ginginianus (Latham, 1790) is a grayish-blue passerine bird with orange orbital skin. It has blackish cap with tufted forehead. Wing patch, under-wing-coverts, and tail-tip are orange buff; bills and legs are orange-yellow. Its call is a ringing tone like, kew, kew, kew, krew, krew, chake-chake.

There are 148 species of sturnids throughout the world of which Bangladesh supports 12 species (Siddiqui et al., 2008). The bank myna is not considered a threatened species in Bangladesh or world, although three sturnids (Asian glossy starling [Aplonis panayensis], braminy myna [Sturnus pagodarum] and pale-bellied myna [Acridotheres cinereus]) have data deficient, three (spot-winged starling [Saroglossa spiloptera], rosy starling [Sturnus roseus] and common starling [Sturnus vulgaris]) vagrant, and others are common in the country. According to IUCN (2009) Red List Category: bank myna is Least Concern species of the world.

Literature review reveals that no published paper is available on record on the conservation of the bank myna, but there are some works mainly on the distribution and taxonomy [for example, Grimmett et al. (1998), Inskipp et al. (1996), Sibley \& Monroe (1993, 1990), Sibley \& Ahlquist (1990), Ripley (1982), Husain (2003, 1979), Harvey (1990), Sarkar \& Sarker (1988), Khan (1982), Rashid (1970), Rashid (1967)]. An attempt was taken in this study to know the interaction between local people and bank myna, threats, demark environmental and human impact on the breeding habitat of the species, and create conservation awareness for the species in Chapai Nawabganj of Bangladesh.

\section{Study area and Methods}

Chapai Nawabganj (formerly known as Nawabganj) is one of the Districts of Rajshahi Division in the northern Bangladesh. Originally it was a Thana of Maldaha District of the British India. After 1947 it was upgraded to a Subdivision of Rajshahi District of East Pakistan (after 1971 became Bangladesh) and eventually in 1984 all Subdivisions of Bangladesh were upgraded as Districts.

Chapai Nawabganj District $\left(24^{\circ} 44^{\prime} 00^{\prime \prime}\right.$ North latitude and $88^{\circ} 12^{\prime} 00^{\prime \prime}$ East longitude), an area of $1,744.33 \mathrm{~km}^{2}$, is bounded by West Bengal of India on the north, south and west. Rajshahi and Naogaon Districts cover the east side. The District comprises five Upazillas (Fig. 1): Chapai Nawabganj, Shibganj, Bholahat, Gomastapur and Nachole. Part of the District lies under Barind Tract and consists of diaras and charland (sandbars develop in river bed). Main Rivers of the area are the Ganges, Mahananda, Pagla, Maraganga and the Punarbhaba (Baby, 2003; Chowdhury, 2003a, b; Taru, 2003). There are about 30 depressions (beels) are present in this area and the larger important ones are Vaeoa, Chatra, Kaubari, 
Amgachi, Baro, Charal, Kolar, Hazardighi, Damas, Bhatia, Singra, Sukrabari Damos, Maricha Dara, Putimari and Kumiradaha.

The present study was carried out during a period from June 2007 to October 2009 in Chapai Nawabganj District of Bangladesh. Engine boats were used to spot the breeding colonies of the bird. Later on microbus and/or local transport were used to reach to the spots. Local assistants were engaged to collect some information also.

Breeding colonies of bank myna was searched along the rivers of Chapai Nawabganj, brickfields and culverts. Searching was also done by interviewing local people. Breeding colonies visited in every month at different parts of Chapai Nawabganj District of Bangladesh. People's interaction and threats of bank myna were assessed by prepared questionnaires and field visits. Randomly selected 100 persons were interviewed through questionnaires

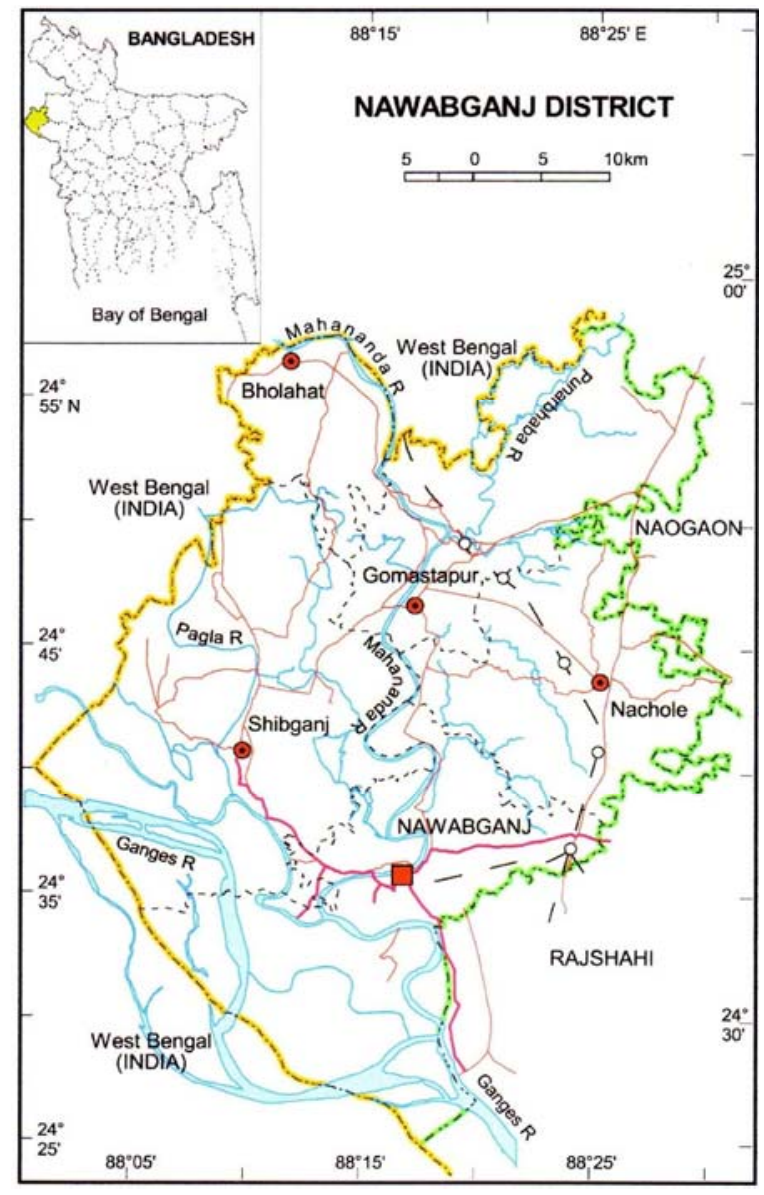

Source: National Encyclopedia of Bangladesh

Fig.1. Map of Chapai Nawabganj

\section{Results and Discussion}

Population: Twenty breeding sites of the bank myna were spotted in the study area, where 45 colonies were found. In total 4,452 birds were counted in 2,226 active nests or holes according to two birds per nest/hole (Table 1). There might be some other members (about 548) of the species whose nests were not found out presents a round figure of 5,000 individuals in the study area. It breeds in colonies of a dozen to forty pairs (Baker, 1926).

Breeding habitat of bank myna: Bank mynas prefer bank of the river, brickfield and culvert hole as nesting habitat. After maturity of the gonad they come to breeding places and become distributed throughout the nesting sites. There are different nesting sites of bank myna in Chapai Nawabganj. These do not only vary for their nature but also differ for their height, shape, size and steepness (Table 2).

Table 1. Breeding population of bank myna during July 2008

\begin{tabular}{|c|c|c|c|c|}
\hline SI.no. & Breeding site & Colony no. & No. of nest & Population \\
\hline 01 & Kalupur & 2 & 500 & 1,000 \\
\hline 02 & Chowdala & 2 & 50 & 100 \\
\hline 03 & $\begin{array}{l}\text { Ranibari } \\
\text { Chandpur }\end{array}$ & 3 & 60 & 120 \\
\hline 04 & Nayadiari) & 2 & 450 & 900 \\
\hline 05 & Fatepur & 5 & 300 & 600 \\
\hline 06 & Mohipur & 3 & 80 & 160 \\
\hline 07 & Sarjan & 1 & 15 & 30 \\
\hline 08 & Poladanga & 1 & 10 & 20 \\
\hline 09 & Raninagar & 1 & 60 & 120 \\
\hline 10 & Nakkatitala & 4 & 150 & 300 \\
\hline 11 & Moheshpur & 1 & 60 & 120 \\
\hline 12 & Boliharpur & 1 & 50 & 100 \\
\hline 13 & Baliadanga & 1 & 150 & 300 \\
\hline 14 & $\begin{array}{l}\text { Baroghoria } \\
\text { brickfields }\end{array}$ & 4 & 150 & 300 \\
\hline 15 & $\begin{array}{l}\text { Palsha } \\
\text { brickfields }\end{array}$ & 1 & 15 & 30 \\
\hline 16 & $\begin{array}{l}\text { Other } \\
\text { brickfields }\end{array}$ & 2 & 40 & 80 \\
\hline 17 & Mokarampur & 1 & 10 & 20 \\
\hline 18 & $\begin{array}{l}\text { Ramdasghat, } \\
\text { Kazigram }\end{array}$ & 1 & 20 & 40 \\
\hline 19 & Diyar & 5 & 40 & 80 \\
\hline \multirow[t]{3}{*}{20} & $\begin{array}{l}\text { Pond banks } \\
\text { (Ranibari, } \\
\text { Nayadiary) }\end{array}$ & 4 & 16 & 32 \\
\hline & Total & 45 & 2,226 & 4,452 \\
\hline & Other & & 274 & $\begin{array}{l}548= \\
5,000\end{array}$ \\
\hline
\end{tabular}

Usually they select nesting places near the human inhabitants where foods are available, although 
sometimes they also select breeding habitats far away from human inhabitants. They collect food both from cultivated fields and homestead gardens.

Table 2. Broken bank height of the breeding sites of bank myna

\begin{tabular}{|c|c|c|c|}
\hline Sl. No. & Breeding site & Minimum (m) & Maximum (m) \\
\hline 01 & Noyadiary & 0.91 & 2.44 \\
\hline 02 & Fatepur & 1.22 & 2.74 \\
\hline 03 & Mohipur & 0.76 & 2.44 \\
\hline 04 & Sarjan & 0.91 & 1.22 \\
\hline 05 & Poladanga & 1.22 & 4.57 \\
\hline 06 & Raninagar & 0.91 & 2.13 \\
\hline 07 & Nakkatitola & 1.22 & 4.27 \\
\hline 08 & Moeshpur & 3.66 & 4.88 \\
\hline 09 & Boliharpur & 1.22 & 3.66 \\
\hline 10 & Baliadanga & 1.52 & 3.05 \\
\hline 11 & Brickfield & 2.13 & 4.57 \\
\hline \multirow[t]{2}{*}{12} & Brickfield ditches & 1.22 & 2.13 \\
\hline & Mean & 1.41 & 3.18 \\
\hline
\end{tabular}

Along with bank myna some other species of breeding birds also select the broken bank of the rivers as breeding ground, of which whitethroated kingfisher (Halcyon symrnensis) and pied kingfisher (Ceryle rudis) are common.

Bank myna chose the following different types of breeding habitat: (1) broken/steep river bank; (2) soil heap or ditch-wall of brickfield;

(3) holes of the culvert; (4) walls of the manmade ditches; (5) water seeping holes of the wall along the rivers; (6) man-made soil steep ground due to collected soil from other purposes; and (7) hay-heaps (per. com. Prof. M. A. Mannan).

Bank myna showed regular local movement or migration. In non-breeding season, no birds were found around breeding sites. They moved to the feeding ground at Godagari of Rajshahi District, which is about $20 \mathrm{~km}$ north from nesting sites. At night, they roost in tall substrates such as bamboo, mango trees, etc. assumed with common myna and pied myna.

Interaction between man and bank myna: Bank myna is a very common bird in the Chapai Nawabganj area. Based on questionnaire, 94\% people are well known about it while 6\% are not familiar. Local people have to some extent knowledge/idea about its life cycle, food and feeding habits, and its usefulness in biological control. About $79 \%$ people think that the bank myna is useful to control insect pests and $12 \%$ have no idea about its usefulness in nature and the rest $9 \%$ have no comments.
Threats to bank myna: The following threats were recognized during this study in the area: (1) flood, (2) children, (3) human for its meat, and (4) animals as predator.

(1) Flood: During June-July, heavy rainfall causes flood to the nesting site. First rain in 2009 damaged 18 nests at Barogharia brickfield. Rain also damaged several nests at Nakkatitala in June 2008.

(2) Children: Major threat of bank myna by human interferes through children. Children damage nests, eggs and nestlings for making fun and funny game by its nestlings. Based on questionnaire, $34 \%$ peoples opined that children damage eggs and nestlings (occasionally collect for meat) of the bank myna.

(3) For meat: Some peoples also capture adults and nestlings for meat, but the snake charmer (bede) community frequently does it. Some students of Ranibari Alia Madrasha at Ranibari Chandpur caught some adults for meat in 2008. Questionnaire based interviews reveal that only $13 \%$ local peoples were in favour of collecting bank myna for meat.

(4) Animals as predator: Snakes, ants and mongooses were identified as predators of bank myna. Snakes were found to be the most effective predators of the bank myna and 5\% people opined that snakes eat bank myna (eggs, nestlings and adults). Snake caste was found outside the brood chamber and also seen to nest inside the brood chamber at Fatepur nesting site. Ants may also kill nestlings and red ants (Formica spp,) killed two nestlings at Nakkatitala nesting site. One villager reported that he saw mongoose to eat nestlings of bank myna.

Environmental impact on breeding colonies of bank myna: The bird is associated with the following impacts to its breeding colonies:

1. Erosion of the nesting bank due to heavy rains, which also damage some of the nests, eggs and nestlings. For instance, in 2008 some nests were damaged at Nakkatitala site and Baroghoria brickfield breeding site due to bank erosion in June and July;

2. Flood and water current inundate and erode some breeding habitat/nesting bank leading to destruction of many nests resulting the birds leaving the sites. For instance, Baroghoria brickfield was inundated in July 2008, which led abandonment of the site; 
3. Occasional excessive drought and sunshine make the breeding site hot causing the birds fail to make nests associated with declined insect populations needed by brooding birds during nestlings;

4. Predators like snakes, crows, raptors and pariah dogs eat some eggs and nestlings;

5. Use of insecticides in the mango orchards, crop fields and vegetable gardens may affect the birds through poisoning by eating insects from these fields. Long term study is, therefore needed to understand the effects of these chemicals; and

6. Rains after May and June make the vegetations luxury with leaves and fruit and the increase of insects' populations help bank mynas feeding nestlings.

Human impact on breeding colonies of bank myna: The following human impacts were observed on the breeding colonies of the birds:

1. Human settlements are very close to the breeding sites of bank myna and their different activities have negative influence on the breeding colony;

2. Usually local inhabitants do not eat the meat of bank myna, but peoples from other places, who visit the area occasionally, eat the meat of nestling/adults. Three times people found catching bank myna for meat in 2008. Similarly, the same incidence was occurred at Ranibari Chanpur area. Likewise, 'Bede' community (snake charmers) are known to eat the meat of bank myna;

3. Children collect eggs and nestlings for fun and sometimes they use sticks to poke the nests killing the nestlings;

4. People living on the eroded banks think that bird holes initiate bank erosion when floodwaters enter into the holes. So some peoples set up nets on the eroded bank close to their houses to prevent the birds from making holes in the banks;

5. Breeding habitats of the species are being disturbed and destroyed due to human settlement close to breeding sites through cutting down trees and bamboos. The species prefers to take rest and socialize on the plants; and
6. Most of the people know that bank mynas are not harmful rather helpful friend of the farmers. They eat a lot of insects from mango orchards, vegetable gardens and crop fields protecting the crop from destruction, hence, increase their crop production.

Future plan- Conservation awareness: The following steps can be taken for the conservation awareness of the species in the breeding area:

1. Making colour poster(s) that will illustrate the positive roles played by the species in nature and distributing to all schools, colleges and local government offices (Union Parishad Chairmen Offices and Upazila Offices) in the area will help to create awareness and protection of the species;

2. Making the small size of colour poster in one side a class routine table in other side of the paper for school students and that will be distributing in all schools in the breeding area of the species, small sticker may be made for the same purpose;

3. Arranging seminars in major schools and colleges about the positive roles of the species;

4. Farmers are fully aware that insects damage their crops and bank myna eats those insects and thus save their crops;

5. This bird is our national property, so we have to save it for the ecological balance in nature of the area and future generations;

6. Hosting few signboards at major breeding sites mentioning the importance of the species in nature in the area for the protection of the breeding sites;

Further research can be carried out on its ecology, behaviour, effects of pesticides on the species and conservation.

\section{Acknowledgement}

The study was carried out with financial supports of the personal research grants of Professor Farid Ahsan of the NUFU Project associated with the Department of Zoology, University of Chittagong, Chittagong. Professor Eivin Roskaft, Dr E. Gereta, Dr B. G. Stokke and Dr. I. M. Mfunda of NTNU (The Norwegian University of Science and Technology) Trondheim, Norway, and Dr David J. Chivers of Cambridge University, UK made some comments on the first draft of the manuscript. We thank them all. We have sincere thanks to Mr. Masud and Mr. Ashraful Islam for their help during the fieldwork. 


\section{References}

Baby, S.N. 2003. Mahananda River. In: Banglapedia: national encyclopedia of Bangladesh, volume 6, (ed. S. Islam). Asiatic Society of Bangladesh, Dhaka, Bangladesh. 345 p.

Baker, E.C.S. 1926. The fauna of British India, including Ceylon and Burma. Vol. III ( $2^{\text {nd }}$ ed.) Taylor and Francis, London, UK. 489 pp.

Chowdhury, M.H. 2003a. Punarbhaba River. In: Banglapedia: national encyclopedia of Bangladesh, volume 8, (ed. S. Islam). Asiatic Society of Bangladesh, Dhaka, Bangladesh. 249 p.

Chowdhury, M.H. 2003b. Padma River. In: Banglapedia: national encyclopedia of Bangladesh, volume 7 , (ed. S. Islam). Asiatic Society of Bangladesh, Dhaka, Bangladesh. 384 p.

Grimmett, R., Inskipp, C. \& Inskipp, T. 1998. Birds of the Indian Subcontinent. Oxford University Press, New Delhi, India. 884 pp.

Harvey, W.G. 1990. Birds in Bangladesh. The University press Limited, Dhaka. 188 pp.

Husain, K.Z. 2003. Birds of Bangladesh: an annotated comparative checklist (for the $20^{\text {th }}$ century). Majid Publication, Dhaka, Bangladesh. 95 pp.

Husain, K.Z. 1979. Birds of Bangladesh. Department of Films and Publications, Government of the People's Republic of Bangladesh, Dhaka, Bangladesh. 64 pp.

Inskipp, T., Lindsey, N. \& Duckworth, W. 1996. An annotated list of the birds of the Oriental Region. Oriental Bird Club, UK. 294 pp.

Khan M.A.R. 1982. Wildlife of Bangladesh: a checklist. The Dhaka University Press, Dhaka, Bangladesh, $172 \mathrm{pp}$.

Primack, R.B. 2006. Essentials of conservation biology, 6th edn. Sinauer Associates, Inc, Publisher Sunderland, Massachusetts, USA. 564 pp.
Rashid, A. 1970. The breeding biology of the jungle myna, Acridotheres fuscus. Unpublished M. Sc. thesis. University of Dhaka, Dhaka

Rashid, H. 1967. Systematic list of the birds of East Pakistant. The Asiatic Society of Pakistan, Dacca. $144 \mathrm{pp}$.

Ripley, S.D. 1982. A synopsis of the birds of India and Pakistan together with those of Nepal, Bhutan, Bangladesh, and Sri Lanka. Bombay: Bombay Natural History Society, Bombay, India.

Sarker, M.S.U. \& Sarker, N.J. 1988. Wildlife of Bangladesh (a systematic list with status, distribution and habitat). The Rico Printers, Dhaka, Bangladesh. 69 pp.

Sibley, C.G. \& Ahlquist, J. 1990. Phylogeny and classification of birds. Yale University Press, New Heaven and London, UK. 706 pp.

Sibley, C.G. \& Monroe, B.L. 1990. Distribution and taxonomy of birds of the world. Yale University Press, New Heaven and London, UK. 1111 pp.

Sibley, C.G. \& Monroe, B.L. 1993. A world checklist of birds. Yale University Press, New Heaven and London, UK. 393 pp.

Siddiqui, K.U., Islam, M.A., Kabir, S.M.H., Ahmad, M., Ahmed, A.T.A., Rahman, A.K. A., Haque, E.U., Ahmed, Z.U., Begum, Z.N.T., Hassan, M.A., Khondker, M. \& Rahman, M.M. (eds.) 2008. Encyclopedia of flora and fauna of Bangladesh, vol. 26. Birds. Asiatic Society of Bangladesh. Asiatic Society of Bangladesh, Dhaka, Bangladesh. 662 pp.

Soule, M.E. 1985. What is conservation biology? BioScience. 35: 727-734.

Taru, M.I. 2003. Punarbhaba River. In: Banglapedia: national encyclopedia of Bangladesh, volume 7, (ed. Islam, S.). 277-278. Asiatic Society of Bangladesh, Dhaka, Bangladesh.

Wilson, E.O. 1992. The diversity of life. The Penguin Press, London. 421 pp. 